\title{
Pittosporum kaalense
}

\author{
Assessment by: Gemmill, C., Veillon, J.-M., Amice, R., Cazé, H., Dumontet, V., \\ Fleurot, D., Garnier, D., Gâteblé, G. \& Maggia, L.
}

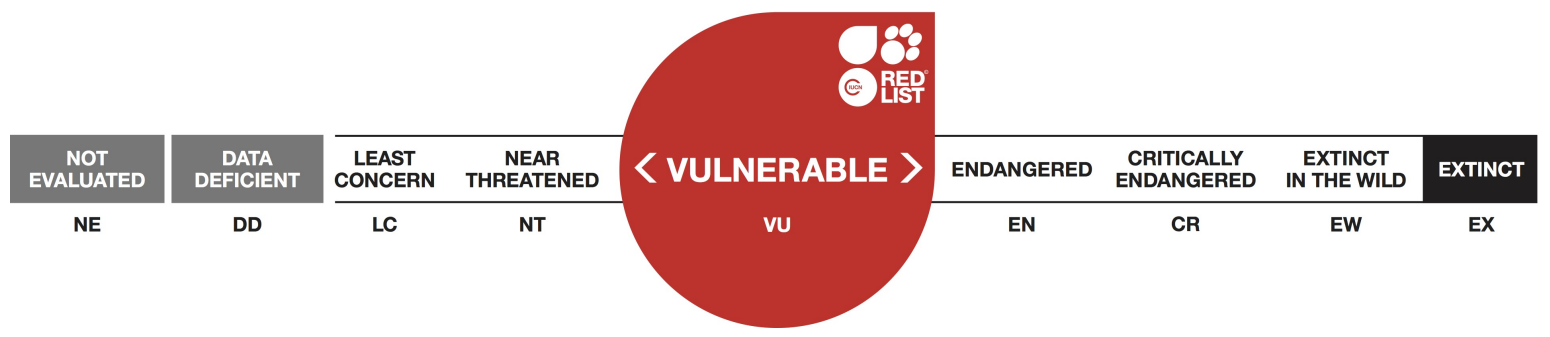

View on www.iucnredlist.org

Citation: Gemmill, C., Veillon, J.-M., Amice, R., Cazé, H., Dumontet, V., Fleurot, D., Garnier, D., Gâteblé, G. \& Maggia, L. 2017. Pittosporum kaalense. The IUCN Red List of Threatened Species 2017: e.T82947494A82951812. http://dx.doi.org/10.2305/IUCN.UK.20173.RLTS.T82947494A82951812.en

Copyright: (C) 2017 International Union for Conservation of Nature and Natural Resources Reproduction of this publication for educational or other non-commercial purposes is authorized without prior written permission from the copyright holder provided the source is fully acknowledged.

Reproduction of this publication for resale, reposting or other commercial purposes is prohibited without prior written permission from the copyright holder. For further details see Terms of Use.

The IUCN Red List of Threatened Species ${ }^{T M}$ is produced and managed by the IUCN Global Species Programme, the IUCN Species Survival Commission (SSC) and The IUCN Red List Partnership. The IUCN Red List Partners are: Arizona State University; BirdLife International; Botanic Gardens Conservation International; Conservation International; NatureServe; Royal Botanic Gardens, Kew; Sapienza University of Rome; Texas A\&M University; and Zoological Society of London. 


\section{Taxonomy}

\begin{tabular}{|c|c|c|c|c|}
\hline Kingdom & Phylum & Class & Order & Family \\
\hline Plantae & Tracheophyta & Magnoliopsida & Rosales & Pittosporaceae \\
\hline
\end{tabular}

Taxon Name: Pittosporum kaalense Guillaumin

\section{Taxonomic Source(s):}

Tirel, Ch. and Veillon, J.-M. 2002. Flore de la Nouvelle-Calédonie, tome 24. Pittosporaceae. Museum d'Histoire Naturelle, Paris.

\section{Assessment Information}

Red List Category \& Criteria: Vulnerable B1ab(ii,iii)+2ab(ii,iii) ver 3.1

Year Published:

Date Assessed:
2017

July 23, 2015

\section{Justification:}

Pittosporum kaalense is an endemic shrub of New Caledonia restricted to the west coast of Grande Terre, with the Baraoua river as the southern border and Mount Kaala as the northern one. This species occurs in dense humid forest and on forest edges between 100 and $900 \mathrm{~m}$ asl. Its area of occupancy and extent of occurrence are respectively 128 and 1,746 km². With a total of six locations of which four are affected by mining activities, the area of occupancy and quality of habitat of $P$. kaalense are considered to be in a state of continuous decline. The population size of $P$. kaalense is unknown but subpopulations seem quite dense. Using criterion B, P. kaalense qualifies for listing as Vulnerable (VU) B1ab(ii,iii)+2ab(ii,iii).

\section{Geographic Range}

\section{Range Description:}

Pittosporum kaalense is an endemic shrub of New Caledonia restricted to the west coast of Grande Terre, with the Baraoua River as the southern border and Mount Kaala as northern border.

\section{Country Occurrence:}

Native: New Caledonia 


\section{Distribution Map}

\section{Pittosporum kaalense}
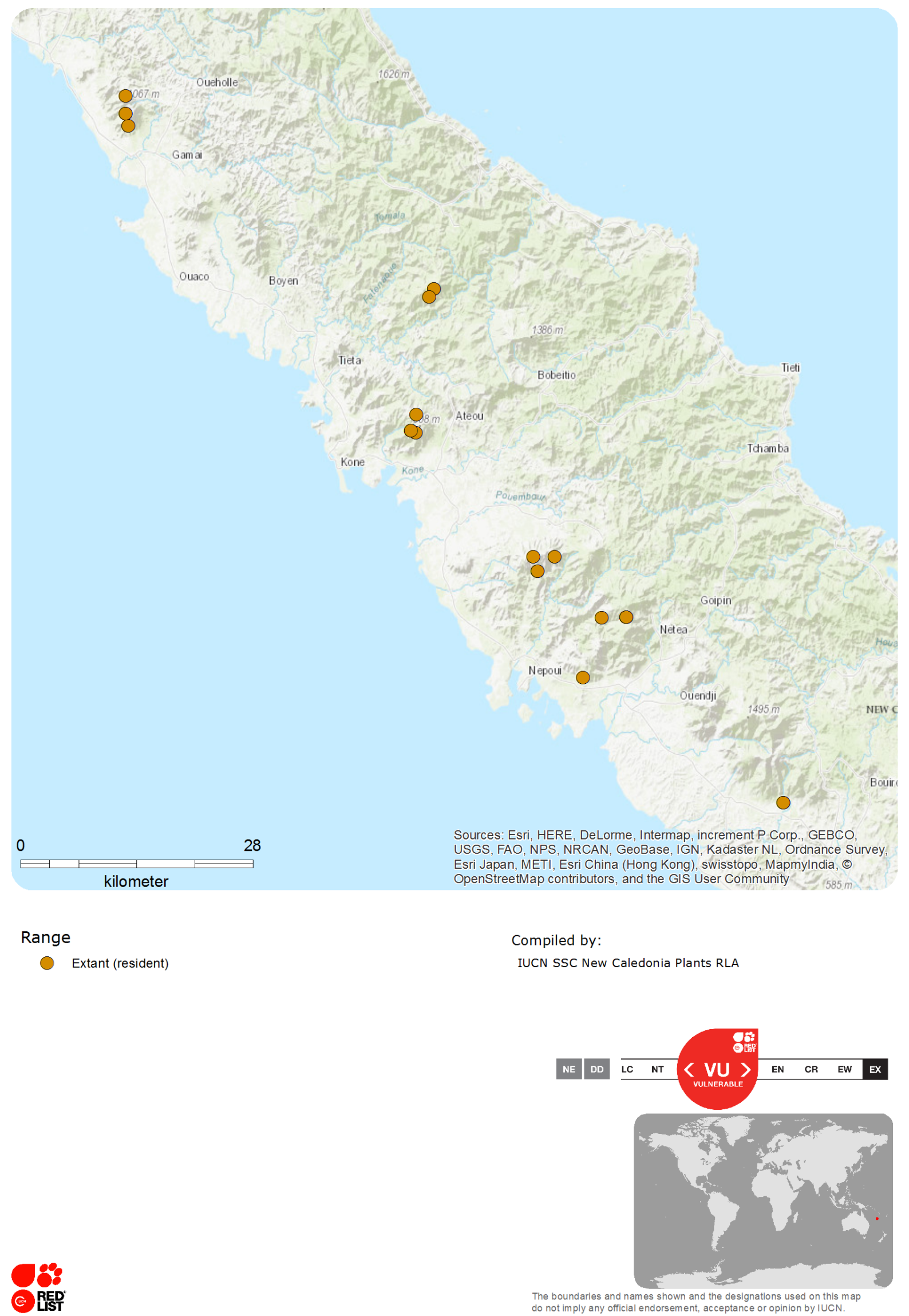


\section{Population}

Population size is not precisely known, but Pittosporum kaalense seems to form quite dense subpopulations.

Current Population Trend: Decreasing

\section{Habitat and Ecology (see Appendix for additional information)}

Pittosporum kaalense is found in dense humid forest and on forest edges between 100 and $900 \mathrm{~m}$ asl.

Systems: Terrestrial

\section{Threats (see Appendix for additional information)}

Due to its predominance on ultramafic massifs, Pittosporum kaalense is highly impacted by past, currently ongoing and future mining activities. New Caledonia contains between $20-30 \%$ of the world's nickel resources. Intense mining activities since the late 19th century has generated soil erosion (1.2\% of bare ground mapped by SPOT5 in 2007). Damage to habitat caused by Rusa Deer (Rusa timorensis) and feral pigs, invasive species in New Caledonia, also constitute major threats.

\section{Conservation Actions (see Appendix for additional information)}

Pittosporum kaalense is not protected by any legislation nor does it occur in any protected areas. Due to its predominance on ultramafic massifs, it should be necessary that some conservation measures and management policies be established on mines to prevent the extinction of this, and other similar, species.

\section{Credits}

Assessor(s): $\quad$ Gemmill, C., Veillon, J.-M., Amice, R., Cazé, H., Dumontet, V., Fleurot, D., Garnier, D., Gâteblé, G. \& Maggia, L.

Reviewer(s): $\quad$ Tanguy, V.

Facilitators(s) and Chanfreau, S.

Compiler(s): 


\section{Bibliography}

Endemia.nc. 2016. Faune et Flore de Nouvelle-Calédonie. Available at: http://www.endemia.nc.

IUCN. 2017. The IUCN Red List of Threatened Species. Version 2017-3. Available at: www.iucnredlist.org. (Accessed: 7 December 2017).

L'Huillier, L., Jaffré, T. and Wulff, A. 2010. Mines et Environnement en Nouvelle-Calédonie: les milieux sur substrats ultramafiques et leur restauration. IAC, Nouméa.

Tirel, Ch. and Veillon, J.-M. 2002. Flore de la Nouvelle-Calédonie, tome 24. Pittosporaceae. Museum d'Histoire Naturelle, Paris.

\section{Citation}

Gemmill, C., Veillon, J.-M., Amice, R., Cazé, H., Dumontet, V., Fleurot, D., Garnier, D., Gâteblé, G. \& Maggia, L. 2017. Pittosporum kaalense. The IUCN Red List of Threatened Species 2017:

e.T82947494A82951812. http://dx.doi.org/10.2305/IUCN.UK.2017-3.RLTS.T82947494A82951812.en

\section{Disclaimer}

To make use of this information, please check the Terms of Use.

\section{External Resources}

For Images and External Links to Additional Information, please see the Red List website. 


\section{Appendix}

\section{Habitats}

(http://www.iucnredlist.org/technical-documents/classification-schemes)

\begin{tabular}{|c|c|c|c|}
\hline Habitat & Season & Suitability & $\begin{array}{l}\text { Major } \\
\text { Importance? }\end{array}$ \\
\hline 1. Forest -> 1.6. Forest - Subtropical/Tropical Moist Lowland & - & Suitable & - \\
\hline
\end{tabular}

\section{Threats}

(http://www.iucnredlist.org/technical-documents/classification-schemes)

\begin{tabular}{|c|c|c|c|c|}
\hline Threat & Timing & Scope & Severity & Impact Score \\
\hline \multirow{2}{*}{$\begin{array}{l}\text { 3. Energy production \& mining }->3.2 \text {. Mining \& } \\
\text { quarrying }\end{array}$} & Ongoing & - & - & - \\
\hline & Stresses: & \multicolumn{3}{|c|}{$\begin{array}{l}\text { 1. Ecosystem stresses }->1.1 \text {. Ecosystem conversion } \\
\text { 1. Ecosystem stresses }->1.2 \text { Ecosystem degradation }\end{array}$} \\
\hline \multirow{4}{*}{$\begin{array}{l}\text { 8. Invasive and other problematic species, genes } \& \\
\text { diseases }->8.1 \text {. Invasive non-native/alien } \\
\text { species/diseases }->8.1 .2 \text {. Named species (Sus } \\
\text { domesticus) }\end{array}$} & Ongoing & - & - & - \\
\hline & Stresses: & \multirow{3}{*}{\multicolumn{3}{|c|}{$\begin{array}{l}\text { 1. Ecosystem stresses }->1.2 \text {. Ecosystem degradation } \\
\text { 2. Species Stresses }->2.2 \text {. Species disturbance } \\
\text { 2. Species Stresses }->2.3 \text {. Indirect species effects }-> \\
\text { 2.3.7. Reduced reproductive success }\end{array}$}} \\
\hline & & & & \\
\hline & & & & \\
\hline \multirow{5}{*}{$\begin{array}{l}\text { 8. Invasive and other problematic species, genes \& } \\
\text { diseases }->8.1 \text {. Invasive non-native/alien } \\
\text { species/diseases }->\text { 8.1.2. Named species (Rusa } \\
\text { timorensis) }\end{array}$} & Ongoing & - & - & - \\
\hline & Stresses: & \multirow{4}{*}{\multicolumn{3}{|c|}{$\begin{array}{l}\text { 1. Ecosystem stresses }->1.2 \text {. Ecosystem degradation } \\
\text { 2. Species Stresses }->2.1 \text {. Species mortality } \\
\text { 2. Species Stresses }->\text { 2.2. Species disturbance } \\
\text { 2. Species Stresses }->2.3 \text {. Indirect species effects }-> \\
\text { 2.3.7. Reduced reproductive success }\end{array}$}} \\
\hline & & & & \\
\hline & & & & \\
\hline & & & & \\
\hline
\end{tabular}

\section{Conservation Actions in Place}

(http://www.iucnredlist.org/technical-documents/classification-schemes)

\section{Conservation Actions in Place}

In-Place Land/Water Protection and Management

Occur in at least one PA: No

Invasive species control or prevention: No

In-Place Species Management

Successfully reintroduced or introduced beningly: No 
Conservation Actions in Place

Subject to ex-situ conservation: No

\title{
Conservation Actions Needed
}

(http://www.iucnredlist.org/technical-documents/classification-schemes)

\section{Conservation Actions Needed}

2. Land/water management -> 2.1. Site/area management

\section{Additional Data Fields}

\author{
Distribution \\ Estimated area of occupancy (AOO) $\left(\mathrm{km}^{2}\right): 128$ \\ Continuing decline in area of occupancy (AOO): Yes \\ Extreme fluctuations in area of occupancy (AOO): No \\ Estimated extent of occurrence (EOO) $\left(\mathrm{km}^{2}\right): 1746$ \\ Continuing decline in extent of occurrence (EOO): No \\ Extreme fluctuations in extent of occurrence (EOO): No \\ Number of Locations: 6 \\ Continuing decline in number of locations: No \\ Extreme fluctuations in the number of locations: No \\ Lower elevation limit (m): 100 \\ Upper elevation limit (m): 900

\section{Population}

Number of mature individuals: $10000-100000$

Continuing decline of mature individuals: No

Extreme fluctuations: No

Population severely fragmented: No

No. of subpopulations: 6

Extreme fluctuations in subpopulations: No

Habitats and Ecology

Continuing decline in area, extent and/or quality of habitat: Yes

Generation Length (years): 0 


\section{The IUCN Red List Partnership}

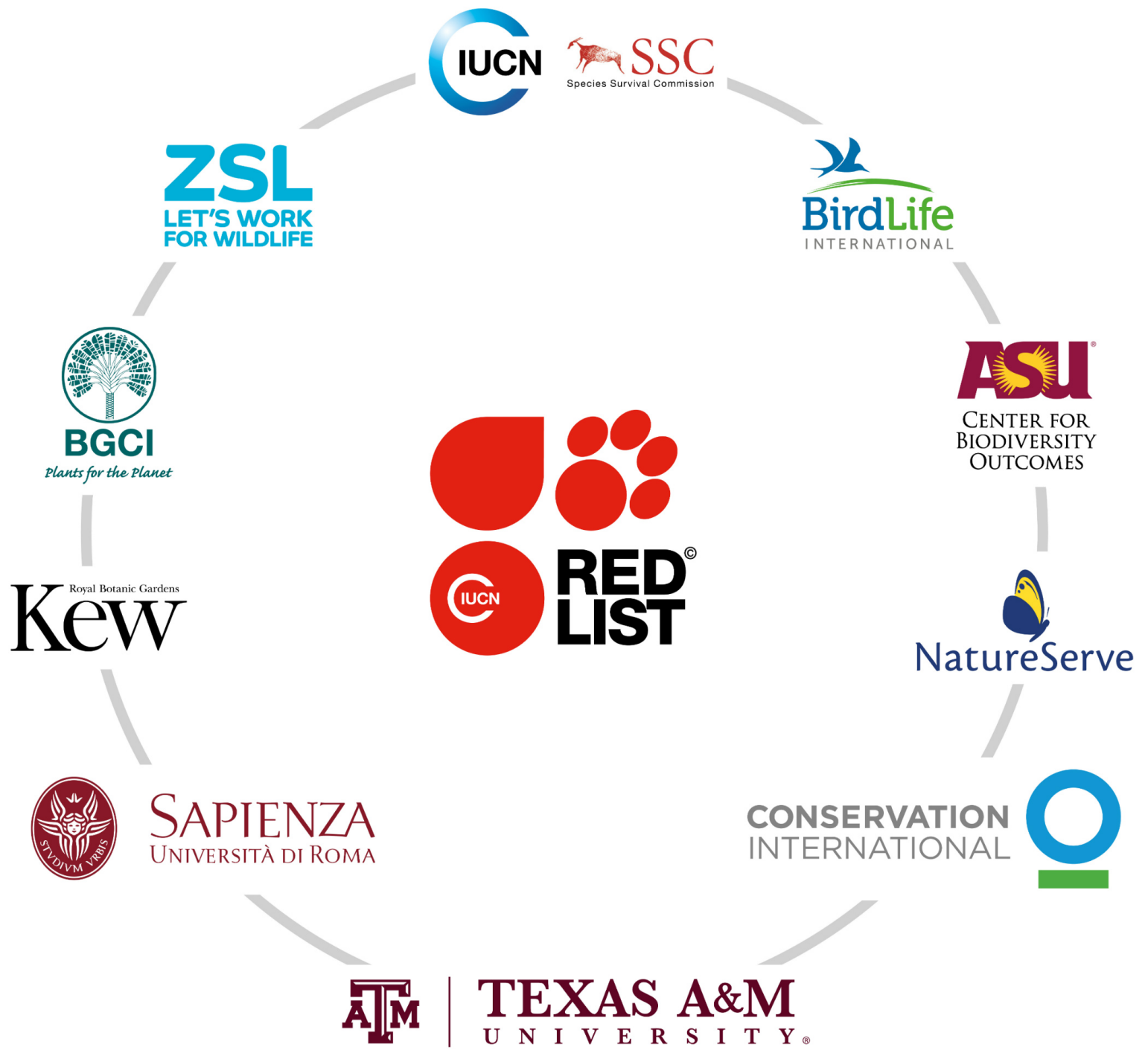

The IUCN Red List of Threatened Species ${ }^{\mathrm{TM}}$ is produced and managed by the IUCN Global Species Programme, the IUCN Species Survival Commission (SSC) and The IUCN Red List Partnership.

The IUCN Red List Partners are: Arizona State University; BirdLife International; Botanic Gardens Conservation International; Conservation International; NatureServe; Royal Botanic Gardens, Kew; Sapienza University of Rome; Texas A\&M University; and Zoological Society of London. 